\title{
Meningkatan Hasil Belajar IPA Materi Sifat-Sifat Benda Melalui Metode Eksperimen Pada Siswa Kelas III SDN 3 Bogangin
}

\section{Aguntoro}

\author{
SD Negeri 3 Bogangin \\ aguntoro138@gmail.com
}

\section{Article History}

received 3/12/2020

\begin{abstract}
The aim is to improve student learning outcomes in science learning material properties of objects through the experimental method as a learning method for Class III SD Negeri 3 Bogangin, Sumpiuh District, Banyumas Regency. Research on improvement of learning with the experimental method as a learning method runs 2 cycles. The results showed that in the initial learning, the students who finished studying were 5 students from 12 children or 41.67 percent. In the first cycle of students who finished studying as many as 9 students from 12 students or as much as 75 percent. In the second cycle of students who finished studying as many as 11 students from 12 students or as much as 91.67 percent. Through the experimental method as a learning method in the science learning process the material properties of objects can improve students' understanding of the properties of solids, liquids and gases, create a more pleasant learning atmosphere and improve student learning outcomes for Class III SD Negeri 3 Bogangin.
\end{abstract}

Keywords: improvement of learning outcomes, experimental method

\begin{abstract}
Abstrak
Tujuan untuk meningkatkan hasil belajar siswa pada pembelajaran IPA materi sifat-sifat benda melalui metode eksperimen sebagai metode belajar Kelas III SD Negeri 3 Bogangin Kecamatan Sumpiuh Kabupaten Banyumas. Penelitian perbaikan pembelajaran dengan metode eksperimen sebagai metode belajar berjalan 2 siklus. Hasil penelitian menunjukkan bahwa pada pembelajaran awal, siswa yang tuntas belajar sebanyak 5 siswa dari 12 anak atau sebanyak 41,67persen. Pada siklus I siswa yang tuntas belajar sebanyak 9 siswa dari 12 siswa atau sebanyak 75persen. Pada siklus II siswa yang tuntas belajar sebanyak 11 siswa dari 12 siswa atau sebanyak 91,67persen. Melalui metode eksperimen sebagai metode belajar dalam proses pembelajaran IPA materi sifat-sifat benda dapat meningkatkan pemahaman siswa terhadap sifat benda padat,benda cair dan benda gas, menciptakan suasana belajar yamg lebih menyenangkan dan meningkatan hasil belajar siswa Kelas III SD Negeri 3 Bogangin.
\end{abstract}

Kata kunci: peningkatan hasil belajar,metode eksperimen

Social, Humanities, and Education Studies (SHEs): Conference Series https://jurnal.uns.ac.id/shes

p-ISSN 2620-9284

e-ISSN 2620-9292 


\section{PENDAHULUAN}

IImu Pengetahuan Alam merupakan ilmu yang mempelajari ilmu bumi dan kehidupannya. Konsep IPA tidak pernah lepas dari dinamika kehidupan sehari-hari dilingkungan sekitar kita. Dalam kegiatan pembelajaran IPA di sekolah dasar sering kali muncul kendala serta hambatan yang bersifat sangat komplek salah satunya dikarenakan kurangnya sumber daya manusia yang tersedia dalam proses pembelajaran baik itu yang ditimbulkan oleh guru, siswa atau peralatan yang kurang memadai.

Sejalan dengan hal tersebut penulis telah menemui kendala yang dialami selama kegiatan pembelajaran di kelas 3 SD Negeri 3 Bogangin untuk Mata Pelajaran IPA materi tentang sifat-sifat benda siswa kurang memahami materi tersebut di buktikan dari hasil nilai ulangan harian masih banyak siswa yang nilai ulangannya di bawah Kriteria Ketuntasan Minimal. KKM mata pelajaran IPA adalah 70 hanya 5 siswa dari 12 siswa yang mencapai KKM, sedangkan yang lain belum mencapai nilai KKM jika diprosentase tingkat keberhasilan hanya mencapai 41,67 persen.

Dengan demikian penulis termotivasi untuk mencari salah satu solusi yang tepat agar hasil belajar siswa menjadi meningkat, yaitu dengan melakukan Penelitian Tindakan Kelas (PTK). Penulis memilih menggunakan metode eksperimen sebagai solusi untuk meningkatkan hasil belajar siswa pada SD Negeri 3 Bogangin. Selama proses pembelajaran yang dilakukan ternyata penulis masih menemui berbagai masalah antara lain: Siswa tidak aktif dalam pembelajaran,kurang berpartisipasi dalam pembelajaran,kurangnya konsentrasi siswa dalam mengikuti pelajaran,masih rendahnya hasil belajar khususnya mata pelajaran IPA materi sifat-sifat benda.

Berdaraskan hasil penelitian,maka penulis menyimpulkan bahwa hal tersebut terjadi dikarenakan guru lebih banyak menggunakan metode ceramah, dan kegiatan pembelajaran kurang menarik perhatian siswa.Dengan demikian penulis menerapkan metode eksperimen sebagai metode belajar pada siswa kelas III SD Negeri 3 Bogangin. Dengan metode eksperimen sebagai metode belajar ini akan terjadi interaksi dalam belajar sehingga terjadi suasana pembelajaran yang menyenangkan sehingga hasil belajar akan meningkat.

Berdasarkan dari latar belakang di atas dapat dirumuskan beberapa permasalahan sebagai berikut : Apakah dengan menggunakan metode eksperimen dapat meningkatkan hasil belajar IPA materi sifat-sifat benda pada siswa SD Negeri 3 Bogangin UPK Sumpiuh Semeter I tahun 2019 ?

Tujuan penelitian adalah untuk meningkatkan hasil belajar siswa pada pembelajaran IPA materi sifat-sifat benda melalui metode eksperimen sebagai metode belajar di kelas 3 SD Negeri 3 Bogangin UPK Sumpiuh.

Hasil penelitian tindakan kelas bermanfaat untuk untuk meningkatkan hasil belajar,menciptakan suasana belajar yang menyenangkan bagi siswa mata pelajaran IPA materi sifat-sifat benda.Bagi guru bermanfaat membantu guru dalam memperbaiki pembelajaran, untuk berkembang secara profesional dan secara aktif,meningkatkan ilmu pengetahuan dan ketrampilan.

Menurut Udin S. Winataputra, dkk (dalam Bell-Gredler 1986 : 1) belajar adalah proses yang dilakukan oleh manusia untuk mendapatkan aneka ragam competencies, skill, dan attitudes. Belajar menurut definisi lama adalah menambah dan mengumpulkan pengetahuan, yang diutamakan definisi ini adalah pengetahuan sebanyak-banyaknya untuk menjadi cerdas atau membentuk intelektual, sedangkan sikap dan keterampilan diabaikan. (Anitah W.S. 2008: 29). Menurut penulis belajar adalah suatu proses pada diri individu untuk memperoleh pengalaman baru dengan jalan mengalami atau latihan.Dengan belajar tentu akan mendapatkan hasil belajar yang didapat oleh siswa.Hasil belajar menurut Anitah (2008 : 53) adalah perubahanperubahan perilaku siswa (behavioral changes) baik aspek pengetahuan, sikap maupun keterampilan. 
Peningkatan hasil belajar siswa merupakan sebuah usaha yang dilakukan antara beberapa pihak yang terkait dalam pengembangan dan pengelolaan pendidikan seperti guru, orang tua siswa (wali murid) dan pihak-pihak lainnya.Peningkatan hasil belajar merupakan hasil yang telah dicapai individu dengan belajar. Setiap individu menginginkan hasil yang sebaik mungkin. Oleh karena itu setiap individu harus belajar dengan sebaik-baiknya supaya prestasi belajarnya berhasil dengan baik.

IImu Pengetahuan Alam merupakan pengetahuan yang sistematis dan tersusun secara teratur, berlaku umum (universal), dan berupa kumpulan data hasil observasi dan eksperimen. Merujuk pada pengertian IPA itu, maka dapat disimpulkan bahwa hakikat IPA meliputi empat unsur utama yaitu: Sikap: rasa ingin tahu tentang benda, fenomena alam, makhluk hidup, serta hubungan sebab akibat yang menimbulkan masalah baru yang dapat dipecahkan melalui prosedur yang benar; IPA bersifat open ended.Proses: prosedur pemecahan masalah melalui metode ilmiah; metode ilmiah meliputi penyusunan hipotesis, perancangan eksperimen atau percobaan, evaluasi, pengukuran, dan penarikan kesimpulan. Produk : berupa fakta, prinsip, teori dan hukum. Aplikasi: penerapan metode ilmiah dan konsep IPA dalam kehidupan seharihari. Keempat unsur itu merupakan ciri IPA yang utuh yang sebenarnya tidak dapat dipisahkan satu sama lain.

Dalam proses pembelajaran IPA keempat unsur itu diharapkan dapat muncul, sehingga siswa dapat mengalami proses pembelajaran secara utuh, memahami fenomena alam melalui kegiatan pemecahan masalah, metode ilmiah, dan meniru cara ilmuwan bekerja dalam menemukan fakta baru. Kecenderungan pembelajaran IPA pada masa kini adalah siswa hanya mempelajari IPA sebagai produk, menghafalkan konsep, teori dan hukum.

Pengalaman belajar yang diperoleh di kelas tidak utuh dan tidak berorientasi tercapainya standar kompetensi dan kompetensi dasar. Pembelajaran lebih bersifat teacher-centered, guru hanya menyampaikan IPA sebagai produk dan siswa menghafal informasi faktual. Siswa hanya mempelajari IPA pada domain kognitif yang terendah. Siswa tidak dibiasakan untuk mengembangkan potensi berpikirnya. Fakta di lapangan menunjukkan bahwa banyak siswa yang cenderung menjadi malas berpikir secara mandiri. Cara berpikir yang dikembangkan dalam kegiatan belajar belum menyentuh domain afektif dan psikomotor. Alasan yang sering dikemukakan oleh para guru adalah keterbatasan waktu, sarana, lingkungan belajar, dan jumlah siswa per kelas terlalu banyak.

Menurut Anitah, (2008 : 5.27) metode eksperimen adalah merupakan metode mengajar yang dalam penyajian atau pembahasan materinya melalui percobaan sesuatu serta mengamati secara proses. Menurut Djamarah (1995) metode eksperimen adalah cara penyajian pelajaran di mana siswa melakukan percobaan dengan mengalami dan membuktikan sendiri sesuatu yang dipelajari. Kemudian Mulyani Sumantri, dkk (1999) mengatakan bahwa metode eksperimen diartikan sebagai cara belajar mengajar yang melibatkan siswa dengan mengalami dan membuktikan sendiri proses dan hasil percobaan.

Menurut Roestiyah (2001:80) Metode eksperimen adalah suatu cara mengajar, di mana siswa melakukan suatu percobaan tentang sesuatu hal, mengamati prosesnya serta menuliskan hasil percobaannya, kemudian hasil pengamatan itu disampaikan ke kelas dan dievaluasi oleh guru.Metode eksperimen adalah cara penyajian bahan pelajaran di mana siswa melakukan eksperimen dengan mengalami dan membuktikan sendiri sesuatu yang dipelajari. Metode eksperimen juga merupakan suatu bentuk strategi pembelajaran yang difokuskan pada kegiatan aktif dan praktis siswa yang mengarah pada pemahaman dan penguasaan materi pembelajaran melalui aktifitasaktifitas nyata dan terwujud dalam sebuah pola pembelajaran yang efektif dan efisien. 


\section{METODE}

Penelitian ini adalah Penelitian Tindakan Kelas dengan menrapkan metode eksperimen dalam kegiatan Pembelajaran. Menurut Sri Anitah W, dkk (2008 : 5.27) metode eksperimen adalah merupakan metode mengajar yang dalam penyajian atau pembahasan materinya melalui percobaan sesuatu serta mengamati secara proses.

Penelitian ini di laksanakan pada bulan Agustus sampai Oktober 2019. Subjek penelitian adalah benda, hal, atau orang tempat data untuk variabel penelitian melekat, dan yang dipermasalahkan. Di dalam sebuah penelitian, Subjek penelitian sangat sentral karena pada subjek penelitian terdapat data tentang variabel yang diteliti berada dan diamati peneliti. (Suharsimi Arikunto, 2000:116).Subjek penelitian dalam penelitian ini adalah siswa kelas III SD Negeri 3 Bogangin Kecamatan Sumpiuh pada semester 1 tahun pelajaran 2019-2020.Penelitian ini di laksanakan selama dua siklus, siklus I dilakanakan pada tanggal 24 September dan siklus ke II dilaksanakan pada tanggal 04 Oktober 2019.

Secara umum prosedur pelaksanaan penelitian tindakan kelas melalui empat tahapan, yaitu perencanaan, pelaksanaan, observasi dan refleksi.

Teknik pengumpulan data yang digunakan dalam penelitian ini adalah pengamatan secara mendalam sebagai metode utamanya, observasi, dan juga dokumentasi. Analisis data adalah proses mengorganisasikan dan mengurutkan data ke dalam pola, kategori, dan satuan uraian dasar sehingga dapat ditemukan tema sehingga dapat dirumuskan hipotesis kerjanya sesuai dengan data, kegiatan yang dilakukan dalam analisis datanya adalah mengatur, mengurutkan, mengolah dan menjabarkannya. Analisis penelitian ini adalah analisis deskriptif kuantitafif,kualitatif dimana dalam penelitian ini selain penyajian hasil berupa data maupun angka peneliti juga menentukan bagaimana cara pengolahan hasil penelitian.

\section{HASIL DAN PEMBAHASAN}

Proses pembelajaran IImu Pengetahuan Alam materi sifat-sifat benda melalui metode eksperimen sebagai metode yang di gunakan dalam perbaikan pembelajaran dikelas III SD Negeri 3 Bogangin Sumpiuh yang dilakukan dalam dua siklus terbukti dapat meningkatkan hasil belajar siswa.

Hasil belajar siswa dari proses perbaikan pembelajaran Ilmu Pengetahuan Alam (IPA) kompetensi dasar sifat-sifat benda melalui metode ekperimen sebagai metode belajar siklus I. Siswa yang memperoleh ketuntasan belajar sesuai dengan ketentuan belajar minimal $\geq 70$ ada 9 siswa $(75 \%)$ sedangkan 3 siswa yang lainnya belum memperoleh ketuntasan belajar. Rata-rata ketuntasan klasiklal dari kegiatan perbaikan Siklus I mencapai 70.

Dari analisis hasil tes formatif pada proses pembelajaran IImu Pengetahuan Alam (IPA) kompetensi dasar sifat-sifat benda melalui metode ekperimen sebagai metode belajar yang dilaksanakan pada kegiatan perbaikan pembelajaran siklus II diperoleh hasil data dari 12 siswa yang mengikuti tes formatif pada proses pembelajaran IImu Pengetahuan Alam (IPA) kompetensi dasar sifat-sifat benda melalui metode ekperimen sebagai metode belajar siklus II berhasil mencapai ketuntasan belajar seluruhnya $(91,67 \%)$ dan sesuai kriteria ketuntasan minimal seara individual $\geq 70$ yang diharapkan.

Dari kegiatan penelitian tindakan kelas yang dilaksanakan dengan perbaikan pembelajaran sebanyak 2 siklus melalui metode eksperimen sebagai metode belajar pada mata pelajaran IPA Standar Kompetensi Mengidentifikasi sifat-sifat benda berdasarkan pengamatan benda padat,cair dan gas sebagai berikut : 
Tabel 1. Rekapitulasi Nilai Tes Formatif Tiap-Tiap Siklus Perbaikan

\begin{tabular}{lllccc}
\hline No & & Kode siswa & \multicolumn{3}{c}{ Nilai } \\
\cline { 3 - 6 } 1 & S-1 & Studi awal & Siklus I & Siklus II \\
2 & S-2 & 45 & 50 & 60 \\
3 & S-3 & $\mathbf{5 0}$ & $\mathbf{7 0}$ & 80 \\
4 & S-4 & $\mathbf{7 0}$ & $\mathbf{8 0}$ & 90 \\
5 & S-5 & $\mathbf{7 5}$ & $\mathbf{8 0}$ & 100 \\
6 & S-6 & $\mathbf{8 0}$ & $\mathbf{9 0}$ & 90 \\
7 & S-7 & $\mathbf{5 0}$ & $\mathbf{7 0}$ & 90 \\
8 & S-8 & $\mathbf{7 5}$ & $\mathbf{8 0}$ & 90 \\
9 & S-9 & $\mathbf{6 0}$ & $\mathbf{7 0}$ & 90 \\
10 & S-10 & $\mathbf{6 0}$ & $\mathbf{7 0}$ & 90 \\
11 & S-11 & $\mathbf{5 0}$ & $\mathbf{6 0}$ & 80 \\
12 & S-12 & $\mathbf{7 0}$ & $\mathbf{7 0}$ & 90 \\
& & Jumlah & $\mathbf{5 0}$ & $\mathbf{5 0}$ & 70 \\
\hline \hline
\end{tabular}

Dari Tabel 1 diperoleh keterangan dari studi awal sampai dengan pelaksanaan perbaikan pembelajaran siklus II, sebagai berikut:

Siswa belum tuntas belajar :

Pada studi awal, siswa yang belum tuntas belajar sebanyak 7 siswa dari 12 siswa atau sebanyak $58,33 \%$.

Pada perbaikan pembelajaran siklus I siswa yang belum tuntas belajar sebanyak 3 siswa dari 12 siswa atau sebanyak $25 \%$

Pada perbaikan pembelajaran siklus II siswa yang belum tuntas belajar sebanyak 1 siswa dari 12 siswa atau sebanyak $8,33 \%$.

Siswa tuntas belajar:

Pada studi awal, siswa yang tuntas belajar sebanyak 5 siswa dari 12 anak atau sebanyak $41,67 \%$.

Pada perbaikan pembelajaran siklus I siswa yang tuntas belajar sebanyak 9 siswa dari 12 siswa atau sebanyak $75 \%$.

Pada perbaikan pembelajaran siklus II siswa yang tuntas belajar sebanyak 11 siswa dari 12 siswa atau sebanyak $91,67 \%$.

Dari keterangan diatas dapat diketahui adanya perubahan nilai hasil belajar yang menunjukan kenaikan hasil belajar siswa atau sesuai dengan kriteria minimal yang ditentukan, kenaikan pada setiap siklus perbaikan lebih lanjut dapat dilihat pada tabel dibawah ini. 
Tabel 2. Rekapitulai Peningkatan Hasil Belajar Siswa Pada Tiap-Tiap Siklus

\begin{tabular}{llllll}
\hline \multirow{2}{*}{ No } & \multirow{2}{*}{ Kegiatan } & \multicolumn{2}{c}{ Siswa belum } & tuntas belajar & \multicolumn{2}{c}{ Siswa tuntas belajar } \\
\cline { 3 - 6 } & & Frekwensi & $\%$ & Frekwensi & $\%$ \\
\hline 1 & Studi Awal & 7 & 58,33 & 5 & 41,67 \\
2 & Siklus I & 3 & 25 & 9 & 75 \\
3 & Siklus II & 1 & 8,33 & 16 & 91,67 \\
\hline
\end{tabular}

Tabel 2. terlihat bahwa setiap siklus perbaikan pembelajaran terjadi peningkatan hasil belajar siswa, peningkatannya adalah sebagai berikut:Dari studi awal kesiklus I hasil belajar siswa naik 33,33 persen.Dari siklus I kesiklus II hasil belajar siswa naik 16,67 persen.

Ada beberapa karakteristik anak di usia Sekolah Dasar yang perlu diketahui para guru, agar lebih mengetahui keadaan siswa khususnya ditingkat Sekolah Dasar. Sebagai guru harus dapat menerapkan metode pengajaran yang sesuai dengan keadaan siswanya maka sangatlah penting bagi seorang pendidik mengetahui karakteristik siswanya. Selain karakteristik yang perlu diperhatikan kebutuhan siswa.

Menururt pendapat pakar pendidikan Howard, salah satu karakteristik anak Sekolah Dasar adalah adalah anak senang bermain bekerja dalam kelompok. Dari pergaulannya dengan kelompok sebaya, anak belajar aspek-aspek yang penting dalam proses sosialisasi, seperti: belajar memenuhi aturan-aturan kelompok, belajar setia kawan, belajar tidak tergantung pada diterimanya dilingkungan, belajar menerimanya tanggung jawab, belajar bersaing dengan orang lain secara sehat (sportif), mempelajari olah raga dan membawa implikasi bahwa guru harus merancang model pembelajaran yang memungkinkan anak untuk bekerja atau belajar dalam kelompok, serta belajar keadilan dan demokrasi. Karakteristik ini membawa implikasi bahwa guru harus merancang model pembelajaran yang memungkinkan anak untuk bekerja atau belajar dalam kelompok. Guru dapat meminta siswa untuk membentuk kelompok kecil dengan anggota 3-4 siswa untuk mempelajari atau menyelesaikan suatu tugas secara kelompok (www.wikipedia.com).

Pemilihan metode eksperimen sebagai metode belajar oleh peneliti pada pelaksanaan perbaikan pembelajaran IImu Pengetahuan Alam Standar Kompetensi Memahami sifat-sifat,perubahan sifat benda dan kegunaanya dalam kehidupan seharihari. karena sesuai dengan karakteristik yang dimiliki oleh siswa SD termasuk siawa kelas III SD Negeri 3 Bogangin. Siswa SD sangat tertarik bermain dengan alam. Siswa senang bermain dengan lingkungan yang jarang mereka temui sehari-hari. Hal ini terbukti dari meningkatnya hasil belajar yang diperoleh dari setiap siklus.

Dari proses perbaikan pembelajaran IImu Pengetahuan Alam (IPA) materi sifatsifat benda di SD Negeri 3 Bogangin melalui metode ekperimen sebagai metode belajar siklus I diperoleh data bahwa siswa yang memperoleh ketuntasan belajar sesuai dengan ketentuan belajar minimal $\geq 70$ ada 5 siswa $(41,67 \%)$ sedangkan 7 siswa yang lainnya belum memperoleh ketuntasan belajar. Rata-rata ketuntasan klasikal dari kegiatan perbaikan Siklus I mencapai 70 \%. Keberhasilan dari kegiatan perbaikan siklus I secara individual mengalami kenaikan yaitu dari studi awal kesiklus I hasil belajar siswa naik sebesar 33,33\%.

Pembelajaran IPA kompetensi dasar sifat-sifat benda melalui metode ekperimen sebagai metode belajar pada siklus I belum berhasil, ketidakberhasilan ini dikarenakan jumlah anggota kelompok terlalu banyak, keterlibatan siswa juga belum maksimal, siswa masih takut dengan keberadan seorang observer. Setelah peneliti melakukan 
diskusi dengan observer dan supervisor, maka pada siklus II perlu ditindaklanjuti dengan mengurangi jumlah anggota kelompok dan pemerataan anggota kelompok.

Dari kegiatan silkus II dapat diperoleh data tentang hasil belajar dari 12 siswa, 11 siswa $((91,67 \%)$ berhasil mencapai ketuntasan belajar sesuai dengan kriteria ketuntasan minimal yaitu $\geq 70$. Sedangkan 1 siswa atau $(8,33 \%)$ belum mencapai ketuntasan belajar. Ketuntasan klasikal mencapai $85 \%$ sesuai dengan kriteria keberhasilan yang ditentukan yaitu $\geq 70 \%$. Namun ketuntasan belajar ini perlu ditingkatkan mengingat antusias siswa yang sangat tinggi terhadap proses pembelajaran IImu Pengetahuan Alam (IPA) kompetensi dasar sifat-sifat benda melalui metode ekperimen sebagai metode belajar.

Berdasarkan hasil observasi, pembelajaran IImu Pengetahuan Alam (IPA) materi sifat-sifat benda melalui metode ekperimen sebagai metode belajar siklus II telah mencapai kriteria keberhasilan yang diharapkan. Keberhasilan ini dikarenakan pengefektifan jumlah anggota kelompok, pemaksimalan peran tutor sebaya dan peningkatan bimbingan intensif yang maksimal.

Kenaikan hasil belajar siswa dapat digambarkan melalui grafik berikut ini:

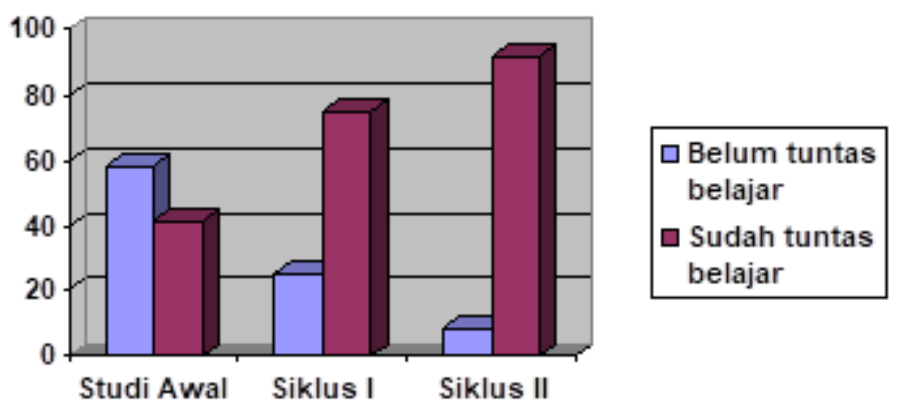

Gambar 1. Peningkatan Hasil Belajar Siswa Pada Tiap-Tiap Siklus.

Dari tabel peningkatan hasil belajar siswa pada tiap-tiap siklus tersebut dapat dilihat bahwa metode eksperimen dapat meningkatkan hasil belajar siswa dalam proses pembelajaran IPA materi sifat-sifat benda melalui penelitian tindakan kelas (PTK) dengan dua siklus, siswa dapat mencapai ketuntasan belajar sesuai dengan kriteria yang ditentukan.

Dari grafik diatas terlihat bahwa pada studi awal, siswa yang belum tuntas belajar sebanyak 7 siswa (58,33\%). Pada siklus I siswa yang belum tuntas belajar menurun sebanyak 3 siswa (25\%). Selanjutnya pada siklus II siswa yang belum tuntas belajar sebanyak 1 siswa (8,33 \%).Dari grafik juga bisa disimpulkan bahwa pada studi awal, siswa yang tuntas belajar sebanyak 5 siswa (41,67\%). Pada siklus I siswa yang tuntas belajar maningkat menjadi 9 siswa (75\%). Selanjutnya pada siklus II siswa yang tuntas belajar sebanyak 11 siswa $(91,67 \%)$.

Dari keterangan diatas dapat diketahui adanya perubahan nilai hasil belajar yang menunjukan kenaikan hasil belajar siswa atau sesuai dengan kriteria minimal yang ditentukan. Peningkatan hasil belajar siswa dari studi awal kesiklus I naik 33,33 selanjutnya dari siklus I kesiklus II terjadi kenaikan sebesar $16,67 \%$. 


\section{SIMPULAN}

Berdasarkan temuan hasil yang diperoleh maka kesimpulan dalam penulis adalah keberhasilan dalam pembelajaran salah satunya dipengaruhi oleh metode yang digunakan oleh guru, metode dalam pembelajaran sangat bervariasi salah satunya adalah metode eksperimen. Seperti yang di lakukan guru dalam Penelitian Tindakan Kelas ,melalui metode eksperimen dapat meningkatkan hasil belajar siswa pada mata pelajaran IPA materi sifat-sifat benda pada SD Negeri 3 Bogangin UPK Sumpiuh. Ketercapaian hasil belajar siswa pada siklus II mencapai 91,67 persen.

Saran dalam penelitian ini adalah Penelitian perbaikan pembelajaran dengan metode eksperimen sebagai metode belajar sudah berjalan 2 siklus, diharapkan peneliti atau guru lain bila akan menggunakan metode ini agar disempurnakan sehingga akan mendapatkan hasil yang lebih baik lagi,Melalui metode eksperimen dapat meningkatkan hasil belajar atau pemahaman siswa terhadap materi tertentu. Metode ini dalam pembelajaran telah memberikan implikasi yang baik, tidak ada salahnya jika metode ini digunakan untuk mata pelajaran lain yang memungkinkan menggunakan metode eksperimen.

\section{DAFTAR PUSTAKA}

Anitah,W.S. 2007. Strategi Pembelajaran di SD. Jakarta : Universitas Terbuka Arikunto,S.( 2002). Manajemen penelitian. Bandung : PT Rineka Cipta.

Hermawan, Asep Henry, 2005, Pengembangan Kurikulum \& Pembelajaran, Jakarta, Universitas Terbuka.

Moleong,L.J. (1989).Metodologi Penelitian Kualitatif.Bandung.CV Remaja Rosdakarya Nasution,S.(2003). Metode Penelitian Naturalistik Kualitatif. Bandung : PT Tarsito.

Ristasa,R.,Prayitno (2006). Panduan Penulisan Laporan Pelatihan Pembelajaran (Penelitian Tindakan Kelas). Purwokerto: UPBJJ UT.

Roestiyah,N.K.(2001). Strategi Belajar Mengajar.Jakarta: PT Rineka Cipta

Sumantri.M.,J.Permana(1999/2000). Strategi Belajar Mengajar. Jakarta : Direktorat Jenderal Pendidikan Tinggi. 